\title{
Biszfoszfonátok előállításának vizsgálata
}

\author{
NAGY Dávid Illés \\ BME Szerves Kémia és Technológia Tanszék, Budafoki út 8., 1111 Budapest, Magyarország
}

\section{Bevezetés}

A biszfoszfonsavak két foszfonsav csoportot és egy P-C-P kötést tartalmazó vegyületek, melyek szerkezete nagyon hasonlít a pirofoszforsavhoz, mely a csontrendszerünk egyik fontos építőeleme (1. ábra). ${ }^{1}$<smiles>[R]C(O)(P(=O)(O)O)P(=O)(O)O</smiles><smiles>O=P(O)(O)OP(=O)(O)O</smiles>

1. Ábra. A biszfoszfonsavak és a pirofoszforsav szerkezeti hasonlósága

Ez a vegyületcsalád a foszfortartalmú gyógyszerkészítmények jelentős csoportját alkotja. Előállításuk tanulmányozásával, optimalizálásával és az irodalomban található zavaros eredmények tisztázásával már közel tíz éve (2008) foglalkoznak a BME Szerves Kémia és Technológia Tanszékének Környezetbarát és Foszfororganikus Kutatócsoportjában Dr. Keglevich György vezetésével és Dr. Grün Alajos közremüködésével, mely munkába 2011-ben kapcsolódtam be. A kutatás szoros együttmüködésben folyik a Richter Gedeon Nyrt-vel, illetve annak dorogi gyáregységével, Dr. Greiner István kutatási igazgató és Garadnay Sándor osztályvezető részvételével.
A biszfoszfonsav-származékok a központi szénatom szubsztitúciójában térnek el egymástól. Az egyik helyettesítő lehet hidrogén vagy klóratom, de a legjellemzőbb a hidroxilcsoport, mely vegyületeket dronsavaknak is neveznek. A másik helyettesítő szerint 3 nagy csoportot különböztetnek meg az irodalomban. Az első generációs molekulák az oldalláncukban nem tartalmaznak nitrogénatomot, míg a második generációs vegyületek nitrogén tartalmú alifás helyettesítővel rendelkeznek, a harmadik generációs származékok pedig N-heterociklusos szubsztituenst tartalmaznak (1. táblázat). ${ }^{2}$

A biszfoszfonsavak biológiailag aktív vegyületek, melyek hatását az oldalláncok jelentősen befolyásolják. Fő terápiás felhasználásuk a posztmenopauzás oszteoporózis (csontritkulás) (2. ábra) kezelése, de a Paget-kór és tumor-indukált hiperkalcémia terápiája során is élvonalbeli szereknek számítanak. ${ }^{1-4}$ Egyes kutatások szerint egyre több adat szól a direkt daganat (mell, prosztata, vese, myleoma multiplex) és parazitaellenes hatásukról is, továbbá rheumatoid arthritis és osteoarthritis (különböző ízületi gyulladások) kezelése során is hatásosnak bizonyultak, így egyre növekszik irántuk az érdeklődés, ezért az előállításuk vizsgálata fontos kutatási terület. ${ }^{1-4}$

1. Táblázat. A Tanszéken ez idáig vizsgált különböző generációs biszfoszfonátok

\begin{tabular}{|c|c|c|c|c|c|}
\hline & Generáció & $\mathbf{R}$ & Név & $\mathbf{X}$ & $\mathbf{Y}$ \\
\hline \multirow{9}{*}{ 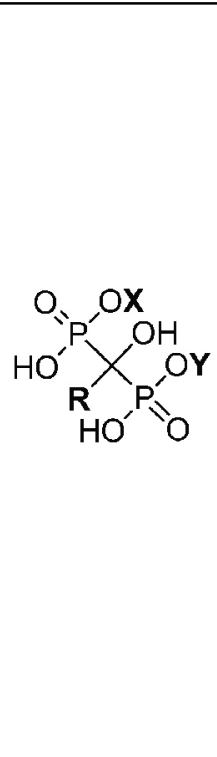 } & \multirow{4}{*}{ Első } & $\mathrm{Me}$ & Etidronát & $\mathrm{Na}$ & $\mathrm{Na}$ \\
\hline & & & Fenidronát & $\mathrm{Na}$ & $\mathrm{Na}$ \\
\hline & & & Benzidronát & $\mathrm{Na}$ & $\mathrm{Na}$ \\
\hline & & & 3-Fenil-propidronát & $\mathrm{Na}$ & $\mathrm{Na}$ \\
\hline & \multirow{3}{*}{ Második } & & $\begin{array}{l}\text { Pamidronát } \\
\text { Pamidronsav }\end{array}$ & $\begin{array}{c}\mathrm{Na} \\
\mathrm{H}\end{array}$ & $\begin{array}{l}\mathrm{H} \\
\mathrm{H}\end{array}$ \\
\hline & & & Alendronát & $\mathrm{Na}$ & $\mathrm{H}$ \\
\hline & & & Ibandronát & $\mathrm{Na}$ & $\mathrm{Na}$ \\
\hline & \multirow{2}{*}{ Harmadik } & & Risedronsav & $\mathrm{H}$ & $\mathrm{H}$ \\
\hline & & & Zoledronsav & $\mathrm{H}$ & $\mathrm{H}$ \\
\hline
\end{tabular}



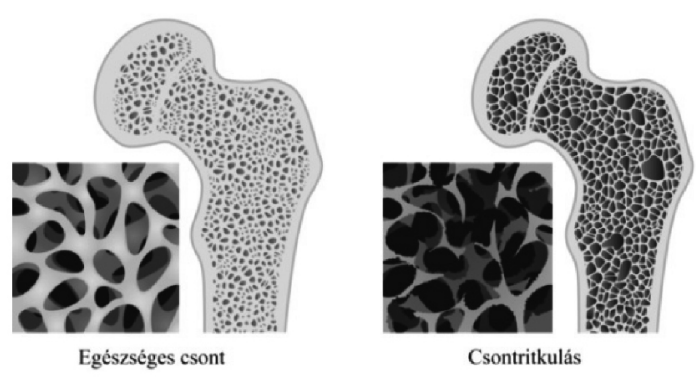

2. Ábra. Egy egészséges és egy csontritkulásban szenvedő beteg csontszövetének szemléltetése

\section{A biszfoszfonsavak előállítási lehetőségei}

A központi szénatomon hidroxilcsoportot nem tartalmazó származékok elöállítására több út is kínálkozik, melyek közül 3 lehetséges utat említenék meg. Egy lehetőség szerint, dijódmetán (1) és 2 ekvivalens mennyiségủ trialkil-foszfit reakciójában („dupla” Arbuzov-reakcióban) keletkező metilénbiszfoszfonát (2) CH-savas karaktere révén C-alkilezhető, és így számos származék (3) állítható elö (3. ábra). ${ }^{5,6}$

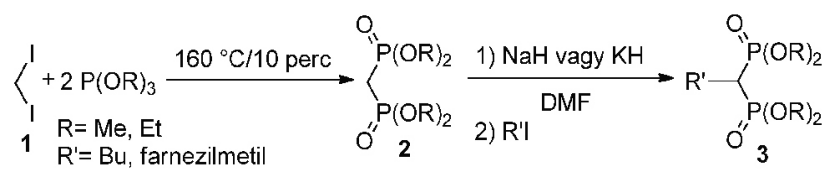

3. Ábra. Biszfoszfonsav-származékok szintézise dijódmetánból kiindulva

Aldehidekből (4) kiindulva is lehetséges biszfoszfonátokat elöállítani. Az első lépés egy addíciós reakció, amikor is a kiindulási aldehidet (4) dialkil-foszfittal reagáltatva $\alpha$-hidroxifoszfonát (5) keletkezik. Az addíciós reakciót követően a hidroxifoszfonát (5) hidroxilcsoportját első lépésben metánszulfonil kloriddal jó távozó csoporttá alakítva, majd az aktivált származékot szintén dialkil-foszfittal reagáltatva a tetraalkil-biszfoszfonáthoz (3) juthatunk (4. ábra). ${ }^{7}$

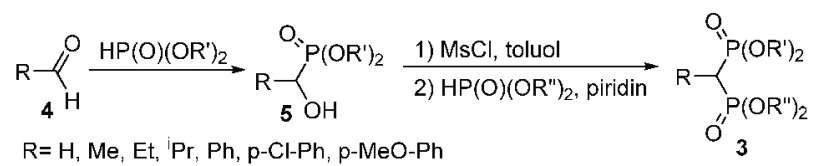

$\mathrm{R}^{\prime}=\mathrm{R}^{\prime \prime}=\mathrm{Me}, \mathrm{Et}$

4. Ábra. Biszfoszfonsav-származékok előállítása aldehidekből kiindulva

$\alpha$-Szubsztituált-metilénbiszfoszfonsav észterek (3) egy különleges elöállítási lehetősége, lítiált dialkil-foszfonát (6) és dialkil-klorofoszfonát reakcióján alapul (5. ábra). ${ }^{8}$

$$
\begin{aligned}
& \text { R= alkil, aril, } \mathrm{Cl} \\
& \mathrm{R}=\mathrm{Me}, \mathrm{Et}, \mathrm{Ph} \\
& \mathrm{R}=\mathrm{Me}, \mathrm{Et},{ }^{n} \mathrm{Pr},{ }^{\mathrm{B} B u}, \mathrm{Ph}
\end{aligned}
$$

5. Ábra. Biszfoszfonsav-származékok szintézise lítiált intermedieren keresztül
Az $\alpha$-szénatomon hidroxilcsoportot tartalmazó származékok szintézise (7) jellemzően két úton történhet. Az egyik lehetősség szerint savklorid (8), trialkil- és dialkil-foszfitok reakciójával történik az á-hidroxi-metilénbiszfoszfonsavak elóállítása. Az első lépés egy Arbuzov-átrendeződésen alapul (savklorid (8) és trialkil-foszfit reakciója), majd a létrejövő á-ketofoszfonát (9) és dialkil-foszfit reakciója szolgáltatja a tetraalkil-biszfoszfonátot (10). A kapott észter (10) savas hidrolízisével állítható elő a dronsav (7) (6. ábra). ${ }^{8}$ A kutatócsoportban az etidronsav, fenidronsav és a benzidronsav észtereinek az előállitását megvalósították mikrohullámú (MW) körülmények között is az említett eljárással..$^{9,10}$

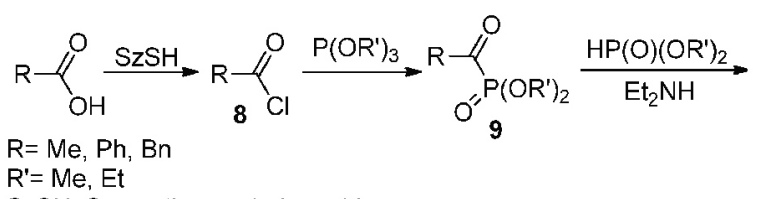

SzSH: Szervetlen savhalogenid

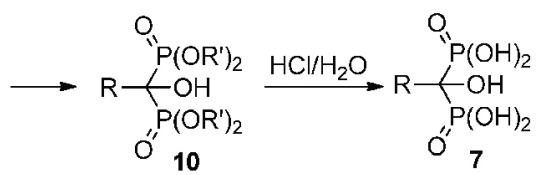

6. Ábra. Dronsav származékok előállitása Arbuzov kezdőlépéssel

A dronsavak leggyakoribb, az iparban alkalmazott előállítása során karbonsavat vagy karbonsavszármazékokat (savklorid, savanhidrid vagy észter) reagáltatnak különböző reagensekkel, mint például foszfor-trikloriddal, foszforossavval, foszfor-oxikloriddal vagy foszfor-trioxiddal. Legjellemzőbb a foszfor-triklorid és foszforossav használata P-reagensként. Az alkalmazott reakcióhőmérséklet $60-100^{\circ} \mathrm{C}$ között változik, a reakcióidő pedig maximum 24 óra. Hidrolízist és szükség szerinti $\mathrm{pH}$ állitást, majd tisztítást követően kapják meg a kívánt terméket (7. ábra). ${ }^{2,11,12}$

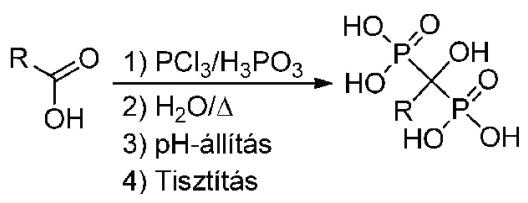

7. Ábra. A biszfoszfonátok legelterjedtebb szintézis útja

A karbonsavból, illetve származékaiból kiinduló szintézisút kedvezőnek tünhet, mivel a reagensek olcsók és könnyen hozzáférhetőek, azonban a reakcióelegyek heterogének, gyakran keverhetetlenek. A reakciók során nagy mennyiségü sósavgáz képződik melléktermékként, és a reakciót követő hidrolízis is rendszerint heves gázképződéssel jár. Ezek a problémák jelentősen megnehezítik a reakciók biztonságos és reprodukálható végrehajtását. $\mathrm{Az}$ irodalomban szereplö adatok számtalanszor megbízhatatlanok és félrevezetőek. A szintézisek során alkalmazott P-reagensek típusai, arányai és a felhasznált oldószerek széles skálán változnak a leírásokban. A leggyakrabban használt metánszulfonsav $(\mathrm{MsOH})$ oldószer mellett klórbenzolt, szulfolánt és toluolt is előszeretettel használnak a dronátok előállításakor. Számos 
esetben oldószer távollétében is leírták több dronát előállítását, azonban a saját tapasztalataink szerint biszfoszfonátokat oldószermentes körülmények között legfeljebb gyenge termeléssel lehet előállítani. Sok esetben a P-reagenseket indokolatlanul nagy feleslegben alkalmazzák, a termelés értékeket legtöbbször a nyerstermékre nézve adják meg, melyek így sokszor irreálisan magasak. A termékek tisztaságát vagy nem adják meg, vagy nem a megfelelö módszerrel történt annak megállapítása. A P-reagensek szerepe, a reakciómechanizmus, az optimális körülmények sem tisztázottak az irodalomban, ráadásul többször egymásnak ellentmondóak, a reakció egyfajta „fekete doboznak” volt tekinthető egészen a közelmúltig. 2,11,12

\section{Tanszéki eredmények}

A tanszéki kutatás során elsőként a zoledronsav (11) és a risedronsav (12) előállítását tanulmányozták metánszulfonsavas közegben. A megfelelő kiindulási karbonsavat reagáltatták különböző mólarányokban vett foszfor-trikloriddal és foszforossavval (8. ábra). ${ }^{13}$
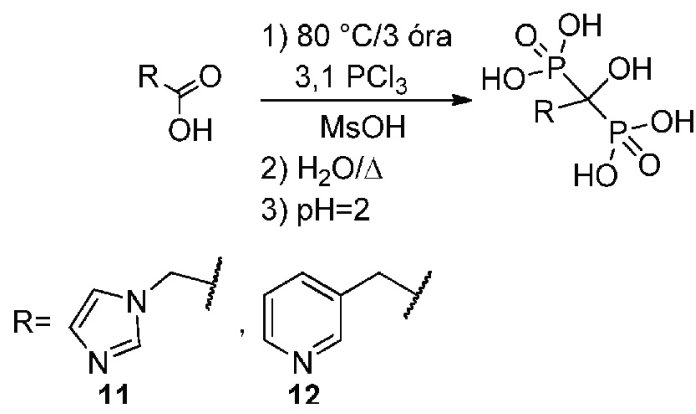

8. Ábra. Zoledronsav (11) és risedronsav (12) elöállítása az optimalizált eljárás szerint ${ }^{13}$

Sikeresen kidolgozták az első racionális szintézist. A mólarányos kísérletek rávilágítottak, hogy MsOH-ban a valódi reagens a foszfor-triklorid, melynek az optimális mennyisége 3,1 ekvivalens, a foszforossav (az alkalmazott oldószerben) csak felesleges ballaszt, mivel alacsony nukleofilitása miatt nem vesz részt a reakcióban. A zoledronsavat (11) 53\%, míg a risedronsavat (12) 74\%-os termeléssel állították elö. Tiszta termékre vetített 30-40\% körüli termelés már jó eredménynek számít a dronátok előállításakor. Az optimális reagens mennyiség (3,1 ekvivalens $\mathrm{PCl}_{3}$ ) alapján javaslatot tettek a reakció mechanizmusára is. A korai elképzelés szerint a kiindulási karbonsav és egy foszfor-triklorid molekula reakciójában képződő savkloridot (13a-b) feltételezték a reakció első intermedierének, amelynek a karbonilcsoportján támadhat a reakció következő lépésében egy újabb foszfor-triklorid molekula, acil-foszfóniumsót (14a-b) eredményezve. Valószínűleg ennek karbonilcsoportján támad ismét a harmadik foszfor-triklorid molekula, biszfoszfónium köztitermékhez (15a-b) vezetve, ami különböző szerkezetekben stabilizálódik (16/17a-b), végül ennek hidrolízise szolgáltatja az $\alpha$-hidroxi-metilénbiszfoszfonsavat $(11,12)(9$. ábra $){ }^{13}$

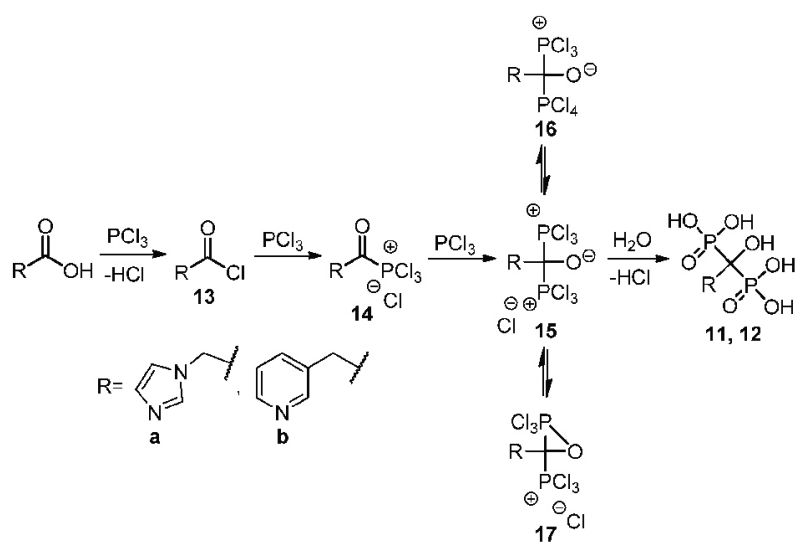

9. Ábra. Biszfoszfonsavak képződésének mechanizmusa egy kezdeti elképzelés szerint ${ }^{13}$

A kutatómunka folyatatásaként, az eljárást kiterjesztették és bizonyították, hogy nincs szükség foszforossavra $\mathrm{MsOH}$ oldószerben a pamidronát ${ }^{14}(\mathbf{1 8})$, alendronát ${ }^{15}$ (19) és az ibandronát ${ }^{15}(\mathbf{2 0})$ elöállítása során, továbbá az etidronát ${ }^{16}$ (21) és a fenidronát ${ }^{17}$ (22) szintézisében sem, amely munkákba már én is bekapcsolódtam (10. ábra).

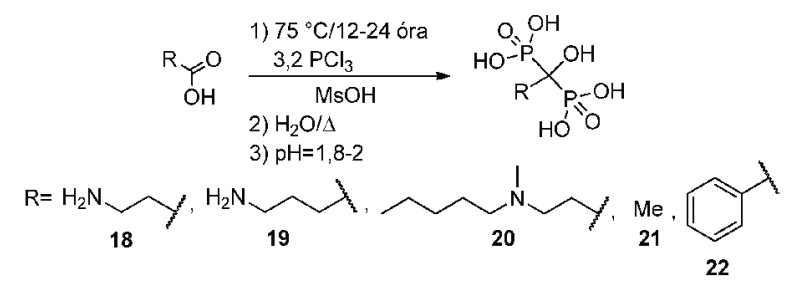

10. Ábra. Metánszulfonsavas közegben végzett eljárás kiterjesztése ${ }^{14-17}$

A második generációs biszfoszfonátokat jó (46-58\%) termeléssel állították elő. Az első generációs etidronát (21) esetén némileg alacsonyabb 36\%-os termelést értünk el, míg a fenidronát (22) szintézisekor 46\%-ot. A korábbi mechanisztikus elképzelést (9. ábra) továbbfejlesztettük, hogy a $\mathrm{MsOH}$ szerepe is értelmezhető legyen. Aktív P-reagensként a foszfor-trikloridból és a MsOH-ból kialakuló anhidrid-típusú intermediert $\left(\mathrm{Cl}_{2} \mathrm{P}-\mathrm{O}-\mathrm{SO}_{2} \mathrm{Me}\right)$ feltételezzük. Az reakció első köztitermékeként a savklorid (24) képződése mellett a karbonsav- $\mathrm{MsOH}$ vegyes anhidridje (25) is elképzelhető. A vegyes anhidrid (25) két úton is képződhet. Létrejöhet a reakcióelegyben képződő savklorid (24) és $\mathrm{MsOH}$ reakciójával, de az esetlegesen képződő metánszulfonsav-klorid (26) és a kiindulási karbonsav (27) reakciójával is. A reakció következő lépésében, az aktivált P-reagens (23) foszforatomja támad a karbonsav származékok (24, 25) karbonilcsoportjának a szénatomjára, majd a létrejövő intermedier (28) mezilát vagy kloridion kilépéssel $\alpha$-keto-származékká (29) alakul, melynek karbonilcsoportjára támadhat ismét egy aktivált anhidrid-típusú reagens (23). Feltételezzük, hogy a képződő köztitermék (30) hidrolízise szolgáltatja a dronsavat (18) (12. ábra). ${ }^{14}$

Meglepő eredményre jutottak a pamidronsav (18) szulfolánban történő előállításának vizsgálatakor. A kiindulási karbonsav ( $\beta$-alanin) (27) és a foszfor-triklorid 
nem lépett reakcióba egymással szulfolánban, nem volt tapasztalható dronát képződés. Ezzel szemben, amikor a foszfor-trikloridot és foszforossavat együttesen használták P-reagensként 2:2 mólarányban, magas 63\%-os termeléssel kapták a tiszta pamidronsavat (18). A P-reaktánsok 3:2 $\left(\mathrm{PCl}_{3}: \mathrm{H}_{3} \mathrm{PO}_{3}\right)$ mólarányú alkalmazásakor is jó $57 \%$-os termelést értek el (11. ábra). ${ }^{14}$

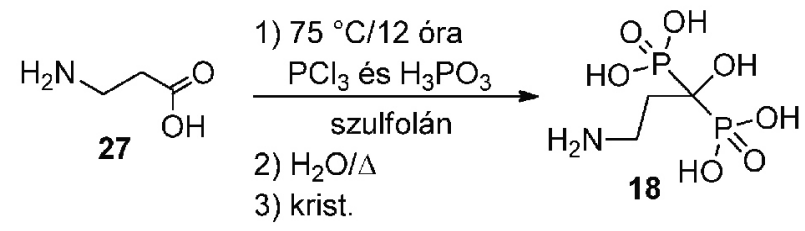

Szulfolánban - annak a MsOH-tól teljesen különböző karakterének köszönhetően - eltérő mechanizmus szerint játszódhat le a reakció. Egy elképzelhető magyarázat szerint, a foszfor-triklorid nem elég reaktív szulfolánban, az aktív P-reagens az 1 ekvivalens foszfor-trikloridból és az 1 ekvivalens foszforossavból kialakuló két foszforatomot tartalmazó addukt $\left(\mathrm{Cl}_{2} \mathrm{P}-\mathrm{O}-\mathrm{P}(\mathrm{OH})_{2}\right)(31)$ vagy szintén az 1 ekvivalens foszfor-trikloridból, de 2 ekvivalens foszforossavból létrejövő három foszforatomot tartalmazó addukt $\left((\mathrm{HO})_{2} \mathrm{P}-\mathrm{PCl}-\mathrm{O}-\mathrm{P}(\mathrm{OH})_{2}\right)$ lehet. A feltételezett P-reaktánsok a 12. ábrán szereplő mechanizmussal analóg módon reagálhatnak a kiindulási karbonsavval, vagy a reakció első lépésében keletkező savkloriddal. ${ }^{14}$

11. Ábra. Pamidronsav előállítása szulfolánban ${ }^{14}$

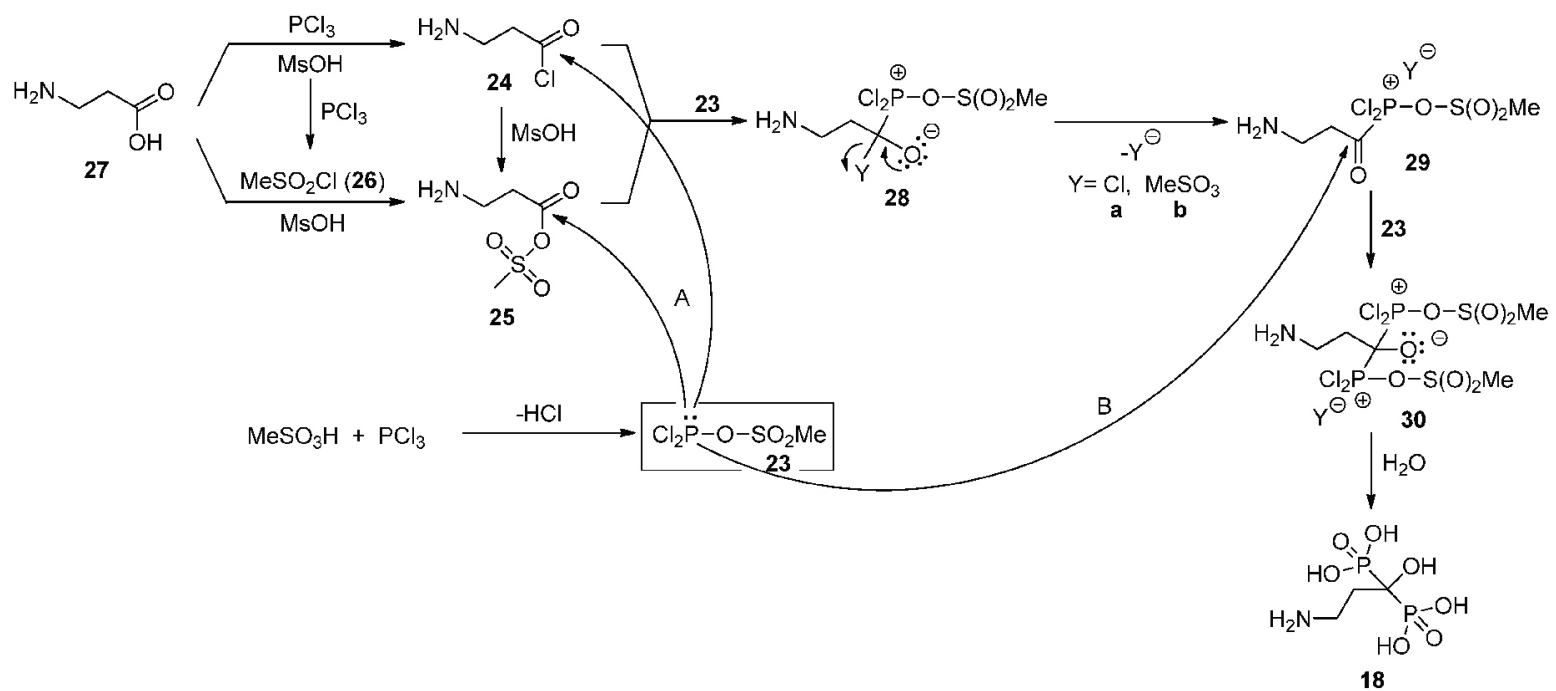

12. Ábra. Biszfoszfonsavak képződésének mechanizmusa MsOH-ban a legvalószínübb elképzelés szerint ${ }^{14}$

Egy másik fontos, második generációs biszfoszfonát, az alendronát (19) szintézisét is megvalósítottuk szulfolánban. Az optimális mólarány esetén $\left(3 \mathrm{PCl}_{3}: 2 \mathrm{H}_{3} \mathrm{PO}_{3}\right)$ közepes, $52 \%$-os termelést értünk el. ${ }^{18} \mathrm{~A}$ szulfolánban végzett kísérletek rávilágítottak, hogy az oldószernek is fontos szerepe van abban, hogy milyen reagensek vesznek részt a dronsavak képződésében. ${ }^{14,18}$

Két további dronát, a benzidronát (32) és a 3-fenilpropiodronát (33) esetén váratlan eredményeket értünk el MsOH-ban. A korábbi tapasztalatainkkal ellentétben nem akkor értük el a legmagasabb termelést, amikor egyedül foszfor-trikloridot használtunk reagensként. A benzidronát (32) szintézisének vizsgálatakor 3,2 ekvivalens foszfor-trikloriddal $46 \%$, míg a 3-fenilpropidronát (33) esetén csupán 2\%-os termeléssel jutottunk az adott dronáthoz. Ezzel szemben a benzidronátot (32) $2: 1 / 2: 2$ és $3: 1 / 3: 2$ mólarányokban vett foszfor-trikloriddal és foszforossavval $\sim 73 \%$ és $\sim 80 \%$-os termeléssel állítottuk elő, míg a 3-fenilpropidronátot (33) 2:3 és 2:4 optimális mólarány mellett $\sim 64 \%$-os termeléssel kaptuk (13. ábra). ${ }^{19,20}$

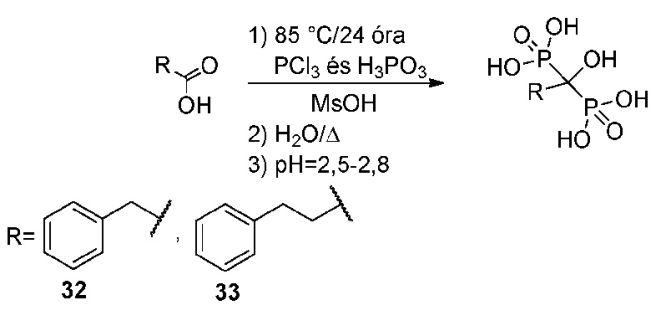

13. Ábra. A benzidronát és a 3 -fenilpropidronát előállítása $\mathrm{MsOH}-b a n^{19,20}$

A szóban forgó két dronát (32 és 33) esetén, érdekes módon $\mathrm{MsOH}-b a n$ is a szulfolánban már feltételezett adduktok $\left(\mathrm{Cl}_{2} \mathrm{P}-\mathrm{O}-\mathrm{P}(\mathrm{OH})_{2}(\mathbf{3 1}),(\mathrm{HO})_{2} \mathrm{P}-\mathrm{PCl}-\mathrm{O}-\mathrm{P}(\mathrm{OH})_{2}\right)$ lehetnek az aktív P-reaktánsok a $\mathrm{Cl}_{2} \mathrm{P}-\mathrm{O}-\mathrm{SO}_{2} \mathrm{Me}(\mathbf{2 3})$ anhidrid-típusú intermedierrel szemben, amely alacsonyabb nukleofilitással rendelkezhet, mint a $\mathbf{3 1}$ és $(\mathrm{HO})_{2} \mathrm{P}-\mathrm{PCl}-\mathrm{O}-\mathrm{P}(\mathrm{OH})_{2}$ reagensek. Kvantumkémiai számítások szerint (B3LYP/6-31G(d,p)//PCM(ACN)) a két (31) vagy három foszforatomot tartalmazó P-reagensek $(\mathrm{HO})_{2} \mathrm{P}-$ része a nukleofilebb, és ez reagál döntő részben a kiindulási karbonsavval (34a-b), savkloriddal (35a-b) vagy a vegyes anhidriddel (36a-b). A karbonsavval (34a-b) való reakció során a legmagasabb az aktiválási energia, így ez a reakció út kevésbé kedvező (14. Ábra). ${ }^{19,20}$ 


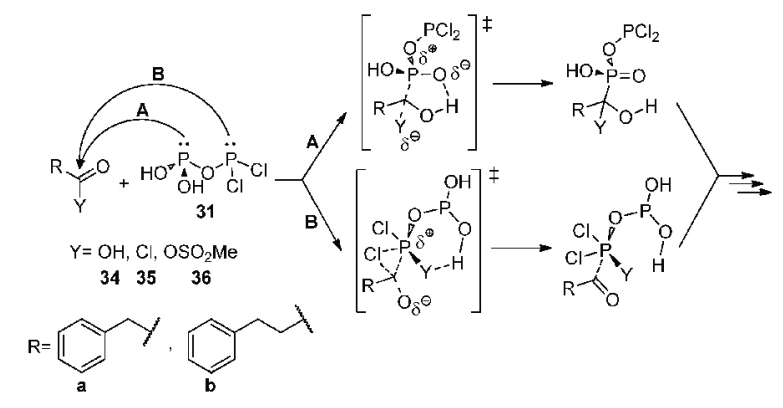

14. Ábra. A benzidronát és a 3-fenilpropidronát képződésének kezdeti lépései ${ }^{19,20}$

A szerves kémiai szintézisek során egyre szélesebb körben használják az ionos folyadékokat (IF), mivel zöld oldószereknek tartják öket. Többek szerint az IF-okra nem oldószerként, hanem csak kisebb mennyiségen adalékként, illetve katalizátorként van szükség. ${ }^{21}$ Célul tüztük ki az $\alpha$-hidroxi-metilénbiszfoszfonsavak előállításának vizsgálatát IF-ok jelenlétében. Azt találtuk, hogy a foszfor-trikloridot és a foszforossavat - a szulfolánban végrehajtott reakciókhoz hasonlóan - együttesen célszerű alkalmazni a reakciók végbemeneteléhez. Érdekes módon az IF-okat a dronsav szintézisek során is csak katalitikus mennyiségben szükséges alkalmazni, nagyobb mennyiségben, oldószerként való alkalmazásukkor romlik a termelés, negatív hatással vannak a reakciókra. A pamidronsavat (18) 0,3 ekvivalens mennyiségü [bmim] $\left[\mathrm{PF}_{6}\right]$ jelenlétében $72 \%$-os, míg az alendronátot (19) 0,3 ekvivalens mennyiségü $[\mathrm{bmim}]\left[\mathrm{BF}_{4}\right]$ IF adalék használatával 66\%-os termeléssel állítottuk elő (15.ábra). ${ }^{18,22}$ A 16. ábra az IF-ok mennyiségének a hatását szemlélteti a termelésre, mely az alendronát (19) esetén különösen jelentős. ${ }^{18,22}$

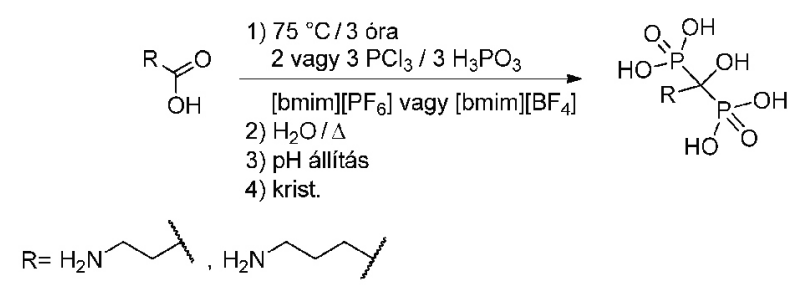

15. Ábra. A pamidronsav és az alendronát előállítása IF-ok jelenlétében ${ }^{18,22}$

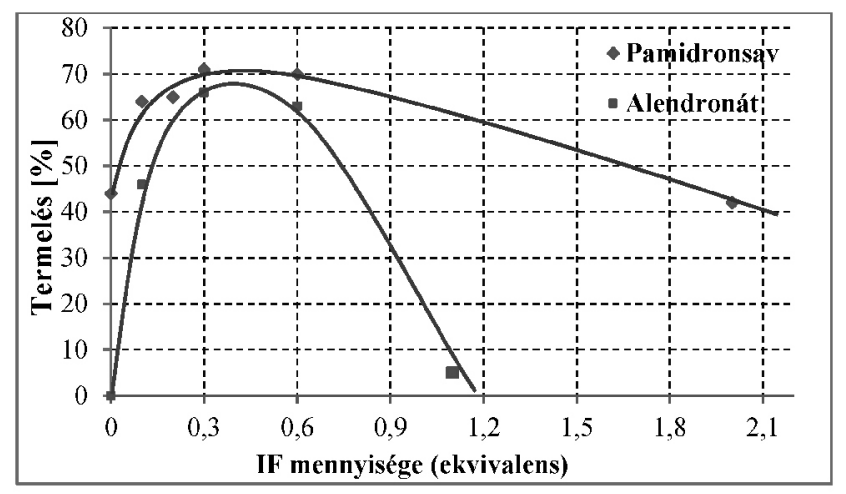

16. Ábra. Az IF mennyiségének a hatása a pamidronsav ([bmim $\left.]\left[\mathrm{PF}_{6}\right]\right)$ és az alendronát ([bmim] $\left.\left[\mathrm{BF}_{4}\right]\right)$ termelésére ${ }^{18,22}$
Azt feltételezzük, hogy az ionos folyadékok a karbonsav-származékok karbonilcsoportjának az elektrofil karakterét tovább növelik, így segítve azok reakcióját az aktivált P-reaktánsokkal (17. ábra). ${ }^{18,22}$<smiles>[Y]P=O</smiles>

17. Ábra. Az IF-ok lehetséges hatása

\section{4. Összefoglalás}

A kutatócsoportban már majdnem egy évtizede foglalkoznak biszfoszfonsavak szintézisének vizsgálatával, melyek a foszfortartalmú gyógyszerkészítmények fontos csoportját alkotják. Célul tüztük ki a dronsavak szintézisének optimalizálását, környezetbarátabbá tételét, a reakciók mechanizmusának felderítését és az irodalomban szereplö zavaros adatok tisztázását.

Megvizsgáltuk több, nemegyszer gyógyszeripari szempontból is fontos dronát előállítását metánszulfonsavban $(\mathrm{MsOH})$, szulfolánban és ionos folyadékok (IF) jelenlétében. Az etidronát, fenidronát, pamidronát, alendronát, ibandronát, risedronát és a zoledronát esetében bizonyítottuk, hogy $\mathrm{MsOH}$-ban a valódi reagens a foszfor-triklorid, melynek optimális mennyisége 3,2 ekvivalens, a foszforossav csak felesleges ballaszt. Szulfolánban és IF-ok jelenlétében, a pamidronsav és az alendronát esetén a reakció lejátszódásához elengedhetetlen, a foszfor-triklorid mellett a foszforossav jelenléte is, rávilágítottunk arra, hogy az oldószernek kulcsfontosságú szerepe van abban, hogy milyen P-reaktánsok vesznek részt a reakciókban. Amikor a foszfor-triklorid a valódi reagens a MsOH-ból és a foszfor-trikloridból létrejövő anhidrid típusú intermedier $\left(\mathrm{Cl}_{2} \mathrm{P}-\mathrm{O}-\mathrm{SO}_{2} \mathrm{Me}\right)$ lehet az aktív P-reagens, míg szulfolánban és IF-ok jelenlétében a foszfor-trikloridból és foszforossavból képződő 2 vagy 3 foszfor atomot tartalmazó addukt $\left(\mathrm{Cl}_{2} \mathrm{P}-\mathrm{O}-\mathrm{P}(\mathrm{OH})_{2},(\mathrm{HO})_{2} \mathrm{P}-\mathrm{PCl}-\mathrm{O}-\mathrm{P}(\mathrm{OH})_{2}\right)$ lehet a támadó ágens. Érdekes módon, két dronát, a benzidronát és a 3-fenilpropiodronát esetén, MsOH-ban is szükséges volt foszforossavat alkalmazni a foszfor-triklorid mellett. Meglepő eredményeket értünk el, amikor IF-okat alkalmaztunk. Bebizonyítottuk, hogy az IF-okra nem oldószerként, hanem csak kisebb mennyiségben adalékként van szükség a reakciókban. Kvantumkémiai számítások alapján javaslatot tettünk a reakciók mechanizmusára is.

\section{Köszönetnyilvánítás}

Szeretnék köszönetet mondani Dr. Keglevich Györgynek és Dr. Grün Alajosnak az áldozatkész munkájukért és támogatásukért. Köszönöm Dr. Mucsi Zoltánnak a kvantumkémiai számítások elvégzését. Köszönjük a Nemzeti Kutatási Fejlesztési és Innovációs Alapnak (K119202) a kutatás anyagi támogatását és a Richter Gedeon Nyrt.-nek az együttmüködést. 


\section{Hivatkozások}

1. Breuer, E. In Analogue-based drug discovery, 2006, 371-384, https://doi.org/10.1002/3527608001.ch18

2. Hudson, H. R.; Wardle, N. J.; Bligh, S. W. A.; Greiner, I.; Grün, A.; Keglevich, G. Mini Rev. Med. Chem., 2012, 12, 313-325, https://doi.org/10.2174/138955712799829285

3. Russell, R. G. G. Bone, 2011, 49, 2-19, https://doi.org/10.1016/j.bone.2011.04.022

4. Catterall, J. B.; Cawston, T. E. Arthritis Res. Ther. 2002, 5, 12-24, https://doi.org/10.1186/ar604

5. Kosolapoff, G. M.; J. Am. Chem. Soc., 1953, 75, 1500-1501, https://doi.org/10.1021/ja01102a524

6. Magnin, D. R.; Dickson, J. K.; Logan, J. V.; Lawrence, R. M.; Chen, Y.; Sulsky, R. B.; Ciosek, C. P.; Biller, S. A.; Harrity, T. W.; Jolibois, K. G.; Kunselman, L. K.; Rich, L. C.; Slusarchyk, D. A. J. Med. Chem., 1995, 38, 2596-2605, https://doi.org/10.1021/jm00014a012

7. Kruse, L. I.; Shah, V. P. US 5204336, 1993.

8. Nguyen, L. M.; Niesor, E.; Bentzen, C. L. J. Med. Chem., 1987, 30, 1426-1433, https://doi.org/10.1021/jm00391a027

9. Grün, A.; Molnár, G. I.; Bertók, B.; Greiner, I.; Keglevich, G. Heteroatom Chem., 2009, 20, 350-354, https://doi.org/10.1002/hc.20558

10. Keglevich, G.; Grün, A.; Molnár, I. G.; Greiner, I. Heteroatom Chem., 2011, 22, 640-648, https://doi.org/10.1002/hc.20727

11. Kieczykowski, G. R.; Jobson, R. B.; Melillo, D. G.; Reinhold, D. F.; Grenda, V. J.; Shinkai, I. J. Org. Chem., 1995, 60, 8310-8312, https://doi.org/10.1021/jo00130a036

12. Nagy, D. I., Grün, A., Garadnay, S., Greiner, I., Keglevich, G. Molecules., 2016, 21, e1046, https://doi.org/10.3390/molecules21081046
13. Keglevich, G.; Grün, A.; Aradi, K.; Garadnay, S.; Greiner, I. Tetrahedron Lett., 2011, 52, 2744-2746, https://doi.org/10.1016/j.tetlet.2011.03.093

14. Kovács, R.; Grün, A.; Németh, O.; Garadnay, S.; Greiner, I.; Keglevich, G. Heteroatom Chem., 2014, 25, 186-193, https://doi.org/10.1002/hc. 21155

15. Kovács, R.; Grün, A.; Garadnay, S.; Greiner, I.; Keglevich, G. Curr. Org. Synth., 2013, 10, 640-644, https://doi.org/10.2174/1570179411310040007

16. Kovács, R.; Nagy, D. I.; Grün, A.; Balogh, G. T.; Garadnay, S.; Greiner, I.; Keglevich, G. Lett. Drug Des. Discov., 2013, 10, 733-737, https://doi.org/10.2174/15701808113109990026

17. Grün, A.; Kovács, R.; Nagy, D. I.; Garadnay, S.; Greiner, I.; Keglevich, G. Lett. Org. Chem., 2014, 11, 368-373, https://doi.org/10.2174/1570178611666140124001516

18. Nagy, D. I., Grün, A., Garadnay, S., Greiner, I., Keglevich, G. Heteroatom Chem., 2017, 28, e21370, https://doi.org/10.1002/hc. 21370

19. Kovács, R.; Nagy, D. I.; Grün, A.; Garadnay, S.; Greiner, I.; Keglevich, G. Lett. Drug. Des. Discov., 2015, 12, 78-84, https://doi.org/10.2174/1570180811666141001004732

20. Grün, A.; Nagy, D. I.; Németh, O.; Mucsi, Z.; Garadnay, S.; Greiner, I.; Keglevich, G. Curr. Org. Chem., 2016, 20, 1745-1752, https://doi.org/10.2174/1385272820666160427115559

21. Kiss, N. Z., Nagy, D. I., Keglevich, G. in Advances in chemistry research; Taylor J. C., Ed.; Nova Science Publishers: New York, 2017; Vol. 37, pp. 121-140.

22. Grün, A.; Nagy, D. I.; Garadnay, S.; Greiner, I.; Keglevich, G. Lett. Drug. Des. Discov., 2016, 13, 475-478, https://doi.org/10.2174/1570180812666151022221805

\section{The investigation of the synthesis of bisphosphonates - Results of a decade}

The bisphosphonic acid derivatives have two phosphonate groups and a P-C-P moiety. They are important drugs in the treatment of bone diseases, such as osteoporosis, Paget-disease, tumor-induced hypercalcaemia. Mostly, they are used as inhibitors of bone resorption. The side chain of the bisphosphonates has a significant impact on the biological activity. The first generation of dronic acid derivatives does not bear a nitrogen atom in the C-substituent, while the members of the second and third generations have aminoalkyl or $N$-heterocyclic substituents, respectively (Table 1 ). The $N$-containing derivatives have a more significant biological effect. ${ }^{1-4}$

The most common synthesis of the $\alpha$-hydroxymethylenebisphosphonic acids involves carboxylic acid or their derivatives (chloride, anhydride or ester) as the starting material, and most typically phosphorus trichloride and phosphorous acid as the P-reactants. The pure product was obtained after hydrolysis and purification (Scheme 7). This method has been applied in the industry, as the reagents are cheap and easily accessible. On the other hand, the reactions have many disadvantages. The reaction mixtures have a high degree of heterogeneity and often unstirrable. During the reaction and the subsequent hydrolysis intensive gas evolvement occurred. The published data are misleading and unreliable, as the required type and amount of the P-reagents have not been clarified. The role of the P-reactants and the solvents have not been investigated, and the mechanism has not been explored. . $^{211,12}$

The research was started by the investigation of the preparation of zoledronate (11) and risedronate (12) in methanesulfonic acid (MSA). The corresponding carboxylic acid was reacted with phosphorus trichloride and phosphorous acid in different ratios (Scheme 8). It was proved that in MSA the real P-reagent is phosphorus trichloride and its optimum amount is 3 equivalents. Phosphorous acid does not participate in the reaction, it is only unnecessary ballast. ${ }^{13}$ Our method was extended for the preparation of pamidronate (18), alendronate (19), ibandronate (20), etidronate (21) and fenidronate (22) (Scheme 10). ${ }^{14-17}$

Based on our experiments, a mechanism was proposed. According to this, anhydride type intermediate $\mathrm{Cl}_{2} \mathrm{P}-\mathrm{O}-\mathrm{SO}_{2} \mathrm{Me}$ (23) was assumed as an activated P-reagents. Carboxylic acid chloride $\mathbf{2 4}$ or carboxylic acid-MSA mixed anhydride $\mathbf{2 5}$ may be imagined as the first intermediate, and the P-atom of species $\mathbf{2 3}$ may attack to the carbonyl group of these compounds (24 and 25). The 
following steps of the reaction mechanism are shown in Scheme 12 .

The other frequently used solvent is sulfolane in the synthesis of bisphosphonates. The preparation of pamidronic acid (18) and alendronate (19) was studied in this solvent. Surprisingly, when only phosphorous trichloride was the P-reactants, no dronic acid was formed. There was need to use both P-reagents $\left(\mathrm{PCl}_{3}\right.$ and $\left.\mathrm{H}_{3} \mathrm{PO}_{3}\right)$ at the same time in a $2: 2$ or $3: 2$ molar ratio (Scheme 11). It was assumed that $\mathrm{Cl}_{2} \mathrm{P}-\mathrm{O}-\mathrm{P}(\mathrm{OH})_{2}(\mathbf{3 1})$ or $(\mathrm{HO})_{2} \mathrm{P}-\mathrm{PCl}-\mathrm{O}-\mathrm{P}(\mathrm{OH})_{2}$ may be the nucleophiles. ${ }^{14,18}$

In the case of benzidronate (32) and 3-phenylpropidronate (33), unexpected results were observed, when MSA was the solvent. In contrast to our earlier experiences, lower yields were achieved when only 3 equivalents phosphorus trichloride were measured in, as compared to the cases when phosphorous acid was also applied beside phosphorus trichloride (Scheme 13). ${ }^{19,20}$

Nowadays, the use of ionic liquids (ILs) is spreading in synthetic organic chemistry. It has been proved in many cases that a catalytic amount of IL may be enough. A project has started aiming at the synthesis of $\alpha$-hydroxymethylenebisphosphonic acid derivatives in IL. During the preparation of pamidronic acid (18) or alendronate (19), $[\mathrm{bmim}]\left[\mathrm{PF}_{6}\right]$ and $[\mathrm{bmim}]\left[\mathrm{BF}_{4}\right]$ were found to be the most suitable IL, respectively. It was demonstrated that the ILs should be applied only as an additive. Their optimal amounts fell in a range of 0.3-0.6 equivalents (Scheme 16). ${ }^{18,22}$ 